\title{
Short-Term Benefits, Long-Term Harm? Alternative Training to Apprenticeships in Norway
}

\author{
Tove Mogstad Aspøy* and Torgeir Nyen \\ Fafo Institute for Labour and Social Research, \\ Borggata 2B, 0650, Oslo, Norway
}

Received: 13.09.2017; Accepted: 23.10.2017; Published: 21.12.2017

\begin{abstract}
Many countries with apprenticeship-based systems of VET face a shortage of apprenticeships. Some countries, including Denmark and Norway, address this supply-demand mismatch by offering alternative school-based routes to vocational qualifications for students not able to secure an apprenticeship. Other countries offer no alternative routes, but focus instead on pre-vocational education and training to prepare students for apprenticeships. This paper discusses the effects on the VET system of a recent Norwegian attempt to organise alternative training primarily as workplace training. Unlike the more established Danish system of alternative training, which relies primarily on school-based training in learning centres, Norway has attempted to make alternative training as similar to apprenticeship-based learning as possible. Most training in the pilot projects takes place in the work environment of a company, rather than in vocational schools. Our paper shows that the students in the pilot projects experience many of the learning and motivational benefits offered by workplace learning in general, and apprenticeships in particular. In certain circumstances, such schemes can improve the chances of completing VET despite for young people without an apprenticeship. However, such training schemes also generate important dilemmas. In particular, there is a risk that full-scale implementation of a system of alternative workplace-based training could reduce the number of new apprenticeships, potentially undermining the apprenticeship model on which Norwegian VET is based.
\end{abstract}

Keywords: VET, Vocational Education and Training, Dual System, Workplace Education and Training, Apprenticeship Contract, Education and Training System, Educational Policy, Learning Motivation

${ }^{*}$ Corresponding author: tove.mogstad.aspoy@fafo.no

ISSN: $2197-8646$

http://www.ijrvet.net 


\section{Introduction}

Apprenticeship-based systems of VET, such as those in Denmark, Germany, Luxembourg, Switzerland and Norway, depend on a balance between the supply of and demand for apprenticeships (see e.g. Busemeyer \& Schlicht-Schmälzle, 2014). However, many countries face or have faced a shortage of apprenticeships. The countries differ in their response to this challenge. In some countries, preparatory, 'pre-vocational' courses are offered to aid individuals in obtaining an apprenticeship. In other countries, alternative routes, leading to the same vocational qualification as an apprenticeship would, are offered.

In Germany, there are no alternative routes to the vocational qualifications, and the result has been that young people have had to wait before completing upper-secondary education (Walden \& Troltsch, 2011, pp. 305-306). They are instead offered preparatory courses in the so-called 'transition system' to gain the necessary skills to obtain an apprenticeship. Through this policy response the unique status of apprenticeships is maintained. Nevertheless, the effectiveness of such pre-vocational training has been questioned (see e.g. Busemeyer \& Iversen, 2012), Generally, the transition system does not provide formal vocational qualifications that give a basis for entering the labour market. Mainly it serves a buffering function, providing a 'waiting loop' for students unable to secure apprenticeships, but a considerable number of students never 'transit' to apprenticeships (see e.g. Solga, Protsch, Ebner \& Brzinsky-Fau, 2014).

However, in other countries, including Denmark, Norway and Austria, there have been attempts to address supply-demand mismatch by introducing alternative routes to vocational qualifications for those unable to obtain an apprenticeship. These routes are alternative routes to the same qualification; students in alternative training register for the same trade examination/test as apprentices. The exclusive nature of apprenticeshipbased dual collective training systems conflicts with a view of education where education is increasingly a right of the individual. Providing an alternative for students not able to secure an apprenticeship can, from this perspective, be seen as a step towards fulfilling that right and preventing exclusion. In both Denmark and Norway, young people who have completed lower-secondary education have a statutory right to upper-secondary education, either academic or vocational. However, the Danish and Norwegian way of organising alternative training differs.

The Danish system of alternative training is primarily school-based, with training centres responsible for providing alternative training. In Norway, alternative training has been organized in different ways in different counties, but in a recent attempt to reorganize alternative training, the training has primarily been delivered as workplace training in companies. In this paper, we use data from the Norwegian case to explore students and others experiences of alternative training organised mostly as workplace training. We then discuss potential system effects of this form of alternative training. First, we analyse whether this way of organising alternative training affects students' learning, motivation and completion 1 . We ask: is there evidence to suggest that organis-

${ }^{1}$ Our data was compiled too early to examine the students transition into the labour market. 
ing alternative training to apprenticeship as work place training will lead more youths to complete vocational upper secondary education? Second, we analyse whether this way of organising alternative training might undermine commitment to the apprenticeship model and reduce the number of apprenticeships, by weakening companies incentives to provide them. In the final section, the Norwegian case is contrasted with the Danish way of organising alternative training to highlight important elements that affect the system effects.

\section{Alternatives to Apprenticeships}

In this section, we describe existing research on alternative training to apprenticeships, which as far as we are aware, is limited to Denmark and Austria, in addition to our own research on Norway. This research addresses how alternative training affects the individual student (learning, motivation, outcomes), but also, to a varying degree, the systemlevel effects of introducing alternatives to apprenticeships in countries with apprenticebased dual collective training systems. We concentrate on the Danish and Norwegian cases, as they are distinctly different ${ }^{2}$. In the section thereafter, we draw on the more general literature on workplace learning and collective skill formation to discuss theoretical expectations of how organising alternative training may influence the VET system.

\subsection{Alternative Training in Denmark}

In Denmark, a school-based alternative ('skolepraktik') has since 1991 been offered to students who cannot find an apprenticeship. Commencing as a temporary measure, it quickly became a permanent alternative (Juul \& Jørgensen, 2011; Jørgensen \& Juul, 2009). From 2013, the Danish school-based alternative has been more strongly institutionalised with the establishment of special training centres ('praktikcentre'). Most are run by upper-secondary schools, and provide alternative training as their main task. The placement in the training centre is meant to be temporary until the students find an apprenticeship. An early evaluation of the centres suggests that alternative training has become more visible and attractive to vocational students (Dannmarks Evalueringsinstitut, 2015), but there is not yet any statistical analysis to support that claim.

Alternative training in Denmark has been, and continues to be, primarily school-based, with much practice work taking place in the schools workshops. Parts of the training are provided in companies as workplace training ('virksomhetsforlagt undervisning', VFU), but the workplace training is limited in time and scope, for instance, by the requirement that students should not participate in production. The rationale for these restrictions is to avoid competition with apprenticeships. The same applies to the requirement that students must have tried to secure an apprenticeship before they can apply for a place in the alternative system. From the outset, there has been a debate about the possibility that alternative training could undermine the dual collective training system. There is

${ }^{2}$ Readers interested in the Austrian case may look to, for instance, Bergmann et al. (2011) and Lassnig (2011). 
a dilemma that alternative training needs to be of sufficient quality to bring students through, but not so attractive that it competes with apprenticeships.

Juul and Jørgensen (2011) found evidence that there is potential for learning in the school-based Danish alternative that is not found in a workplace-based model. There is more room for reflection and mistakes, and the training can be planned in accordance with the individuals learning needs (Juul \& Jørgensen, 2011, p. 296). There is also more time for the students to gain theoretical knowledge in conjunction with the development of their practical skills. The school-based alternative education is, however, not without its challenges. Students do not develop the same social skills and work discipline as they would in a work environment, nor do they experience the gradual socialization and adoption of norms that comes from participating in a work community (Juul \& Jørgensen, 2011, p. 296). Thus, they miss out on the benefits of workplace learning (see e.g. Illeris, 2011). Also, although they might do minor commissioned work, mostly they do not produce goods and services that a customer is going to use, which reduces student motivation. Juul and Jørgensen (2011) note that employer resistance to alternative training was more related to the lack of socialisation into a working life culture than to a lack of vocational skills. They also note that there is (or at least was in 2011) a broad consensus on the advantages of the dual collective training system. Both employers and government see school-based training as second best to apprenticeships (Juul \& Jørgensen, 2011, p. 300).

Although alternative training is a minor element in the Danish education and training system, it is more than a marginal phenomenon. According to figures from the Danish Ministry of Education, about 11 percent of those in vocational upper-secondary education in September 2016 were registered as students in school-based alternative training. Since 1991, that figure has fluctuated with the situation in the training (and labour) market. Research on the Danish system of alternative training has shown that students in alternative training have a more disadvantaged socio-economic background than apprentices. Furthermore, they fare worse after graduation than apprentices, with lower employment rates and a more volatile position on the labour market (Jørgensen \& Juul, 2009).

\subsection{Alternative Training in Norway}

Apprenticeships play a central role in the Norwegian VET system. The number of new apprenticeships each year is currently around 19-20,000, which amounts to almost 30 percent of a yearly birth cohort. Most initial vocational education and training follows the so-called $2+2$ model, where two years of school-based training are followed by a twoyear apprenticeship. The regional county administrations are responsible for fulfilling the individual's statutory right to upper-secondary education, including providing the two years of school-based vocational education. The county administrations are also responsible for providing alternative training in the third year if the student is unable to secure an apprenticeship.

There is little formal regulation of alternative training, apart from that it must last at least one year. As a result, alternative training has been organised differently in different 
counties and in different trades. As in Denmark, alternative training in Norway has been regarded as second-best to apprenticeships (see e.g. Meld. St. 20 (2012-2013); Aspøy \& Nyen, 2015). Alternative training has generally not been marketed to students and has had low participation and completion rates. About 30 percent of all vocational students who apply for an apprenticeship fail to secure one after two years at vocational school. However, only a few of those participate in alternative training. Only 3 percent of all trade certificates in 2014-2015 were achieved by students in alternative training, mostly due to low participation rates.

Previous research on the organisation and outcomes of alternative training in Norway is limited. Nyen, Skålholt and Tønder (2013) found employment rates one year after graduation to be lower among students from alternative training than among apprentices (although the differences are small). Furthermore, government statistics show a significantly lower completion rate among students in alternative school-based training than among those with apprenticeships. Aspøy and Nyen (2015) find that participants in alternative training have lower school achievements and have been more absent from school than those who were able to secure an apprenticeship. When analysing the sub group who have applied for an apprenticeship, but failed to secure one, participants in alternative training typically have a medium level of school achievement. One interpretation is that the high achievers look for better options because of the low esteem for alternative training, and that low achievers are difficult to reach and drop out.

From the autumn of 2013, five Norwegian counties received a government grant for experimenting with improved alternative training for students lacking apprenticeships. The background for the initiative to reorganise alternative training was the existing system's lack of appeal to young people, its low esteem in the labour market, and poor participation, completion and transition rates. Efforts were made to make the school-based alternative more similar to apprenticeship-based learning. The guidelines for receiving a government grant stipulated that the alternative training must last at least 18 months (longer than the standard one-year minimum duration), and that a substantial amount of the training should take place in the work environment of a company. The workplace training must also be planned in cooperation with representatives from local businesses, employer organisations or training offices (which are jointly owned by a group of businesses).

Workplace training was emphasised because of the perceived weaknesses of more school-based forms of alternative training. Students in school-based training did not have the benefit of participating in a professional work community, nor were they exposed to basic workplace norms/socialisation. Furthermore, students with poor school achievements and high absence rates were often tired of school, and not motivated by more school-based education and training.

It is important to note that the legal status of students in alternative training in Norway is very different from that of apprentices, as Table 1 shows. While apprentices are employed by the company and receive a wage stipulated in a collective agreement, a student in alternative training is not employed and receives no wage. Some companies in the pilot project decided on their own initiative to pay students a wage, but they were not expected or required to do so. 
Table 1: Apprentices vs. students in alternative training (at a workplace) in Norway

\begin{tabular}{lcc}
\hline & Apprentices & Students in \\
\hline learning venue & Workplace & Workplace \\
Employed & Yes & No \\
Receives a wage & Yes & No \\
Has a training contract & Yes & No \\
Barriers for dismissal & Medium & Low \\
Responsible for progress & Company & School \\
Responsible for assessment & Company & School \\
Company must be certified as & & \\
training establishment & Yes & No \\
\hline
\end{tabular}

\section{Potential Effects on the Collective Training System}

Apprenticeships are (part of) a collective training system based on a combination of school-based and workplace-based learning. In this section, we discuss potential effects of introducing different forms of alternative training on the collective training system. We draw on two strands of literature, first the research on learning in the workplace, and second the literature on collective skill formation and institutional change.

\subsection{Workplace Learning and School-Based Learning}

Existing research suggests that organising alternative training as mostly school-based has different merits to organizing alternative training as mostly workplace-based. The Norwegian case offers the opportunity to analyse the consequences of organising alternative training mostly as workplace training.

There is a substantial body of research on workplace training as part of vocational education and on the integration of school-based learning and workplace-learning (Colley, James, Tedder, \& Diment, 2003; Fuller \& Unwin, 2004; Illeris, 2011). The benefits of workplace training for vocational learning are well described in the literature. Colley et al. (2003) describe learning as becoming; as a gradual, identity-shaping process of becoming a skilled worker. Learning takes place by performing real work tasks, in a work context where the skills are actually used, and by receiving feedback and perhaps even recognition from experienced skilled workers/members of the work community. These social aspects of learning are difficult to emulate in the schools workshop. On the other hand, school-based training offers more time for theoretical reflection, without the pressure of production (Juul \& Jørgensen, 2011). It also offers a greater opportunity 
for trying and failing. In a school setting it may also be easier to plan education and training according to a set of goals (curricula) that cover the relevant aspects of the trade, than in a company where production places certain constraints on training.

Workplace training offers different types of benefits. First, there are the benefits related to learning the trade, or trade-specific skills. Second, there are benefits of learning certain extra-functional skills, such as 'good work habits' and the ability to show up on time, cooperate with others, work under stress etc. (Streeck, 2012, p. 325). Existing research suggests that organising alternative training as workplace training, to a greater extent than school-based training, might allow for the learning of general workplace norms ('extra-functional skills') and for integration into a trade community (learning trade-specific norms).

\subsection{Actors and Interests Within a Collective Training System}

While organising alternative training in the workplace may have its merits and shortcomings from a learning perspective, introducing alternative training may also have system effects beyond the effects on the individuals learning, motivation and completion. Collective training systems such as apprenticeships are fragile institutional arrangements (Busemeyer \& Trampusch, 2012, p. 4). Path dependency in the form of cognitive and normative constraints and cost-benefit considerations may preserve existing arrangements to some degree, especially by keeping employers committed to the collective training system. However, such arrangements depend on a delicate balance of interests, and the continued commitment of companies, associations and the state. Historical institutionalism sees institutions as legacies of previous power struggles between actors with partly shared and partly conflicting interests. In a dynamic, historical institutional perspective, the current institutional structure does not only constrain actors, but also influences what strategies for institutional change the actors may choose (Thelen, 2010). Such changes can happen through reform or through gradual institutional change. In the case of a collective training system, all actors may pursue other options, which is what make such systems fragile and can cause them to falter. In particular, companies may opt out of the collective system. Ryan (2001) argues that companies remain committed to the apprenticeship system through a combination of rational company behaviour (if wage differentials are smaller than the productivity difference between skilled and unskilled labour) and regulation/collective action by associations and the state. External monitoring of skills is one of the most important regulatory aspects as it provides credible commitments to training which (also) allow companies to offer a lower wage in the training period (Dustman \& Schoenberg, 2012).

Apprenticeship schemes exist also in countries that cannot be characterised as having a collective skill formation regime. While such schemes are not similarly embedded in a collective governance system and usually play a lesser role in employers' recruitment strategies, such schemes also rely on companies willingness to offer apprenticeships. Although our interest in alternative training comes from an interest in how it influences collective (and hybrid) training systems, our discussion about incentives below applies to all situations where apprenticeships and qualifications acquired through apprenticeship 
play a role for recruitment into the relevant labour market.

Introducing alternative training to apprenticeships alters the set of options available to companies and other actors the collective training system relies on. Companies might reassess their participation in the system. If alternative training takes place in schools, the companies may be content to let the schools take responsibility for the training. If alternative training takes place mostly in the workplace, the companies will face a choice of whether or not to take in students as workplace trainees. The capacity of companies to provide training is limited. Alternative work-based training schemes may cause displacement effects by reducing the companies' demand for apprentices, especially if students are unpaid while apprentices command a salary. A number of other factors will influence these decisions, including the 'quality'/trainability of trainee students compared with apprentices, the companys motivation for offering apprenticeships in the first place, and how quickly a student or apprentice can become productive within the trade. The effect on the collective system as a whole of such company decisions will of course depend on the size and scope of the alternative training scheme, as well as the supply-demand balance in the relevant parts of the labour market.

Furthermore, other actors may also be influenced by the existence of alternative training. Students may put less effort into securing an apprenticeship if they know that alternative training will be provided. Counties and schools might also more easily settle on organising alternative training instead of putting in the extra effort to help students secure apprenticeships. Generally, the existence of any alternative to apprenticeships has the potential to undermine ownership of and support for the dual collective training system and adversely affect the supply of apprenticeships (Juul \& Jørgensen, 2011). However, the effect of alternative training on the collective system is likely to be dependent on how alternative training is organised. The workplace based alternative in Norway seems more likely to have adverse effects on firms' incentives to provide apprenticeship than the school based alternative in Denmark, as firms in Norway have the option to take unpaid students in alternative training instead of offering apprenticeship.

\section{Data and Methodology}

The empirical part of the paper is based on the authors evaluation of a set of Norwegian pilot projects providing alternative training for young people unable to secure an apprenticeship (Aspøy \& Nyen, 2015). The projects were run in five counties in Norway. The training began in the 2013-2014 school year, and continued into 2014-2015, with 243 participants. The small-scale nature of the scheme means that large-scale system effects are not likely to be observed. Instead, inferences will be drawn from the effects on various actors' incentives and motivation to participate in the project. Data used in the evaluation of the Norwegian projects consist of qualitative interview data supplemented by quantitative data on completion/dropout.

Qualitative interview data were collected from all five counties. Two to three schools were selected as cases within each county, giving a total of eleven schools. Training took place over 18 months, and interviews were made in two rounds, during the first 
and last six months of training. 51 students were interviewed in the first round, and 27 from the same pool of students in the second. The students interviewed came from different schools, regions and VET programmes. The interviews in the first round were face-to-face interviews lasting around 30 minutes. The students were asked about their choice of trade, about their efforts to find an apprenticeship, and the reason behind accepting the alternative training. They were also asked to describe their tasks and how they perceived the quality of the training, their work conditions and what support they received from teacher and company. The second round interviews were conducted by telephone, and lasted around 20 minutes. The students were then asked to describe how their training situation had developed since the last time. Had they obtained the trade certificate, or were they planning on doing it soon? In addition, we interviewed a number of teachers (22), school and project administrators (16), companies (16) and training offices (6) involved in the planning and implementation of alternative training for the students interviewed. We also interviewed county administrators (18) and leaders of regional tripartite bodies (4). Teachers were interviewed in both rounds, first faceto-face, and in the second round by telephone, all lasting around one hour. Project administrators were also interviewed in both rounds, by telephone, with a duration of around 40 minutes. The main themes of all of these interviews were the planning and implementation process, how various parties were involved, how training was organised, their motivation to participate and how they perceived the quality of the training. The companies were also asked about their policy on taking on apprentices. The qualitative material covers two thirds of the schools involved in the projects. Although our study is qualitative, we wanted to ensure that most segments of the student population and participating companies were included.

All interviews were recorded and transcribed verbatim, and all interviewees, with the exception of the county administrators and leaders of tripartite bodies, were anonymised. The interview data was broken down to different themes. Patterns and exceptions in the material were thoroughly identified and coded. The selection of students may be a source of bias, as teachers helped us recruit students, and voluntary participation led to a degree of self-selection in both the first and second rounds. Any bias would probably be towards a more positive student assessment of the projects. Selection bias is negligible in three of the eleven cases, as almost all students were interviewed. On the employer side, selection bias may be more significant, as interviews were difficult to arrange and several companies were not interviewed. Any employer bias would likely be towards the employers who are most interested and engaged in helping young people. Quantitative data about completion/dropout within the projects were reported by the project administrators in the counties to the research team in reply to a questionnaire. These data are considered valid and reliable, with clear definitions of various outcomes.

\section{Results of the Norwegian Pilot Project}

In this section, we first discuss whether organizing training in the workplace gave students a better chance of obtaining a vocational qualification. The interviews revealed that the 
alternative training did yield a partly positive outcome at the individual level (Aspøy \& Nyen, 2015). Completion data shows that for some students (27 percent), the training period worked as intended from the education authorities' point of view: the student received the necessary company-based training for taking the formal exam and obtaining a trade certificate within 18 months. For other students (18 percent), the trainee position (student in alternative training) transitioned into a regular apprenticeship after some time, normally three to five months. In these cases, the possibility of an apprenticeship contract was signalled by the employer from the beginning. In other words, nearly half of the students managed to obtain vocational qualifications or use alternative training to transit to an apprenticeship. Nevertheless, 40 percent of the students quit the training programme. They either failed to find a trainee position, or they left the company before completing the programme.

Lack of success can generally be traced back to difficulties finding relevant trainee companies, and the confusing distribution of responsibility between teachers and employers. In some cases, training companies did not have a clear training plan or even relevant training opportunities. As opposed to apprenticeship training, schools were responsible for the follow-up of student training. However, this was not always well organised. Teachers often lacked experience with the content of apprenticeship training, as this part of the curriculum was not a part of their ordinary responsibilities. A lack of motivation also became an issue when students experienced the absence of pay as problematic. In the following section, we discuss, in more detail, the reasons why workplace training led to a successful outcome in some cases, but not in others. Further, we examine whether this way of organising alternative training might undermine commitment to the collective, apprenticeship-based training model on which Norwegian VET is based, and reduce the number of apprenticeships, by weakening companies incentives to provide them.

\subsection{Workplace Learning Equals Individual Success - or Failure?}

Workplace training formed a core in the pilot project 3 . This was considered imperative among all actors involved. In many cases, students experienced this workplace training as valuable and learning-intensive. The training was generally highly individualised, meaning that the ratio of school-based learning to workplace training was adapted to fit the student. Most students in the pilot project participated in workplace-based training, and most students spent more than half the time in companies. A typical ratio of schoolbased and company-based training was three days a week at the company, and two days in school. Often, however, the students were allowed to spend almost all their training in the company.

The school was responsible for the follow-up of the students during workplace training, and only in a few cases did the company take responsibility for every aspect of the training. Despite this, the interviews revealed that the students in alternative training often felt like regular apprentices. Often, but not always, positive learning experiences and the general well-being of the student in alternative training seemed to be directly

\footnotetext{
${ }^{3}$ Except in one case of a company-in-school-model for a group of IT students.
} 
connected to the notion of being a 'normal' apprentice. A student illustrates the feeling of belonging, where the only perceived difference was that she did not get paid:

I've never been an apprentice, so I don't know what that's like. But it's almost the same. But you work two hours more, and you get paid [when you're an apprentice], that's the only thing. I feel like everyone else.

Some students also emphasised the benefits of a combination of school-based and workplace-based training. A healthcare student explained how the time spent in school allowed her to work on her mandatory records during the day, with advice from teachers. In her opinion, the regular apprentices had it harder as they had to do this work in addition to a full-time job. In this cases, thus, success was linked to workplace training but also the training that deviated from regular apprenticeship training. In another case, training for industrial machinery mechanics was organised under the responsibility of one single company. The students enjoyed thorough follow-up by the advisors at the company. Their training had similarities to that of the apprentices in the same company, but it was more centred on training in the workshop than training at the factory plant. This way of organising the alternative training was highly beneficial to the individual student, and the quality was praised by the students themselves as well as the company and the school where the students were formally registered. The company was an experienced training company. In both of these cases, the students knew that they were treated differently to the apprentices. Nevertheless, they experienced the benefits of being fully included in a workplace. Success of workplace training did not, therefore, depend fully on the student feeling like an apprentice or being assigned real work tasks, but on the experience of being trained within a 'real' company by 'authentic' skilled workers, and feeling included in the work environment.

The alternative training scheme was, structurally speaking, located in a grey area between school and work, characterised by a lack of clear rules, responsibility and general knowledge about what alternative training entailed. While the legal rights of both apprentices and regular school students are formalised and clear, the rights for students in workplace training are not. Despite their formal status as 'students', the participants are neither regular students nor apprentices. This ambiguity sometimes led to both confusion and frustration for students as well as teachers and employers, even when students were given the same tasks as a regular apprentice. The responsibility was to a great extent left with the schools, and even the individual teachers. Many of these teachers had no previous experience of apprenticeship training, as their domain is normally the two school-based years. Employers, on the other hand, were sometimes uncertain of their own responsibility.

Many students experienced not getting paid as highly problematic. For some, this was first and foremost related to pecuniary loss, as described by this healthcare student:

\footnotetext{
${ }^{4}$ However, the costs of the training exceeded the nationally-allocated resources.
} 
It's just that there's no opportunity to get paid. We do the same as those with an apprenticeship contract, five days a week, but we get nothing. I find it a bit hard. We have rent, electricity, I have a car - I'm thinking that I have to sell it.

A full-time job as a trainee left the student with little time for part-time work. Full-time trainee work combined with paid part-time work did occur, however; for instance, in the curious case of a student who worked without pay at a grocery store during weekdays, and as a regular paid employee at the same store on Saturdays. Although making students perform unpaid labour clearly is morally dubious if they do productive work, the students themselves did not necessarily question the ethics of their training - some of them claimed to be content with their situation. Thus, in order to achieve success within the goals of the project, the students had to be integrated in the work community without experiencing not getting paid as a stigma.

The benefits of workplace training presuppose that the learner is integrated into the workplace environment, and that he or she learns both the trade itself and some crucial extra-functional skills (Juul \& Jørgensen, 2011; Streeck, 2012). Some of the interviews with teachers, however, indicated a somewhat simplified conception of the benefits of workplace training. For some, the importance of workplace training was not only a question of the many benefits of being part of a work community, but rather of not being at school. This is illustrated by a teacher who reflected on the idea of organising a merely school-based alternative for a group of students of whom many are tired of school. When contrasting workplace learning to school-based learning, she stated:

To me, organising this [alternative training] at the school's premises just wasn't right. These are students with a lot of absenteeism; they have struggled in school and sort of muddled through. The last thing they want is to spend another year in school.

As much as this understanding seems reasonable, the emphasis on not being at school, meddled with the emphasis on any kind of workplace training as intrinsically good can result in unintended consequences. In some cases, students did not get to perform relevant tasks. A student explained how he felt that the training he received was inferior to that of the apprentices:

A trainee student cannot get the same competence-based jobs unless he's an apprentice. You have to learn how to be independent and think for yourself and stuff like that, but if I go on as a trainee student, they will keep handing me the same tasks. And that won't teach me anything.

In other cases, the aim of job experience completely outweighed the aim of relevant work and the social skills and work discipline - the extra-functional skills displaced the aspect of actually learning a trade. This was illustrated by an IT student who had, when a trainee slot in an IT company proved to be hard to find, been sent to work for a company where his main task was pulling cables. He stated the following: 
I don't understand why it was so important that I worked for a company that had nothing to do with IT.

To this student, the benefits of the trainee position were unclear. To sum up, the trainees' tasks were sometimes less learning-conducive than the apprentices'. If organised in this manner, it is doubtful that students having completed alternative training would be as attractive as regular apprentices on the labour market, and they might not acquire the necessary competence to obtain the trade certificate. However, the interviews also provided examples of alternative training of a higher quality.

In this section, we have discussed whether the Norwegian pilot projects provide evidence to suggest that organising alternative training in companies has system benefits when it comes to students' learning, motivation and completion of alternative training. The evidence is mixed, with different experiences. The chances of a successful outcome are seemingly higher where there are companies willing to take on a level of responsibility for the trainee student close to the level of responsibility companies take for apprentices.

\subsection{Actors and Interests in the Pilot Project}

In this section, we discuss whether our findings suggest that alternative training will have long-term effects on companies decisions to take on apprentices. We also consider how schools' efforts in securing apprenticeships for their students may change if workplacebased alternative training expands.

In what ways can such alternative training influence employers' decisions to take on apprentices? Will the existence of an alternative training scheme weaken companies' incentives for offering apprenticeships? Looking at reasons why employers take on apprentices in the first place, and how they differ according to trades' and companies' apprenticeship tradition, may help us understand how alternative training could affect employers' decisions to take on apprentices. The Norwegian pilot projects suggest that introducing alternative training in companies might have different effects in industries where apprenticeships are well established compared to industries where apprenticeships are less embedded.

A survey from 2012 showed various reasons why companies in Norway take on apprentices. Companies receive state subsidies for each apprentice, which is regarded as a significant incentive. But also the recruitment of new employees, preserving the trade, and social responsibility are important reasons why companies in Norway take on apprentices. The recruitment reason is less prevalent in health and social care, hotels/restaurants and retail (Høst, Skålholt \& Nyen, 2012). Apprenticeships are weakly embedded within health and social care, retail and the service sector in general in Norway (Nyen \& Tønder, 2014). In the public sector, the decision to take on apprentices is usually made higher up, at the political decision-making level. Within healthcare, for example, there is no scope for a local nursing home to take on more apprentices than the number stipulated by the relevant authorities (Høst et al., 2012).

The reasons why companies take on students (in alternative training) overlap to a great extent with reasons why companies take on apprentices recruitment and social responsi- 
bility (see also Leemann \& Imdorf, 2015). The interviews with employers revealed three different reasons for taking on students in alternative training: 1) social responsibility 2) recruitment via transition from alternative training into apprenticeships, 3) recruitment, but not necessarily through apprenticeships. Employers representing trades with longer apprenticeship traditions expressed a greater normative commitment to the apprenticeship system, and some explained that recruitment via apprentice contract was their motivation to participate. To some training companies with a tradition of taking on apprentices, keeping a student as unpaid labour was unheard of. Two employers expressed their concerns on this issue. They both represented an industry with a long apprenticeship tradition - construction. Their main concern was the risk of creating an "A team and a B team" among young people undergoing training. In effect, however, the trainee period functioned as a trial period, giving the employers the opportunity to test a potential apprentice before committing to an apprenticeship contract.

An employer at a data electronics company saw the benefit in offering the student an apprenticeship contract after a trial period, because they would then be more in control of the training content. This employer did not have other apprentices:

As long as we're in control of the [apprentice's] development and training, it [offering an apprenticeship contract] works to our advantage.

An apprenticeship was thus considered ideal in terms of future recruitment. An employer in a large manufacturing company, on the other hand, clearly stated that taking on apprentices was their first priority, but in addition, that they also considered it their social responsibility to offer quality training through the alternative training system. This company had a clear apprenticeship profile.

In other cases, employers took on students in alternative training without any intention of offering them an apprenticeship contract, but still with the idea of future recruitment in mind. This was illustrated by a teacher talking about a student within media graphics, who had found a trainee slot in a newly-started e-design company:

Teacher: "There are few apprenticeships within the trade [media graphics artist], and everything worked perfectly with this company. So...he'll be offered a job there after completion."

Interviewer: "Why wasn't he offered an apprenticeship contract?"

Teacher: "They didn't have the money."

This illustrates how the supply of trainee students may hamper companies' motivation to take on apprentices, even when recruitment of new workers is the goal. An important question is how employers perceive the students without an apprenticeship. If they are seen as a challenged group in the eyes of the employers, they might be less attractive as labour. Both employers and training offices, however, stated that students without an apprenticeship may just have been unlucky, due to a shortage of apprenticeship slots, and could still be good workers.

The example of a student working without pay in the grocery store during weekdays but as an employee during weekends, mentioned earlier, is a clear case of a student whose 
training resembled productive work more than actual training. Especially in the retail sector, where trainees can become productive quickly, there is a risk of the student ending up as unpaid labour. Whether the training scheme entails unpaid labour in disguise or actual training, is a crucial matter. Productive unpaid labour may be attractive labour, which could in turn undermine companies willingness to take on apprentices. In public healthcare and retail stores belonging to chains or franchise agreements, the decision to take on apprentices was generally made at an upper-management or political decision-making level. The limited autonomy of the individual enterprises allowed them to take on an unpaid student, but not a paid apprentice. The teacher interviews suggest that in many cases, convincing companies to take on student trainees could at times be easier then convincing them to take on an apprentice. To be able to take on an apprentice, the company must be registered as an apprentice company, entailing some formal prerequisites. In most cases, there was no such requirement for the alternative training. It is not unreasonable to expect that this could weaken the continuous efforts in Norway to recruit new apprenticeship companies and to expand VET into the service sector.

\section{Discussion and Conclusion}

This paper asks: what are the effects on the dual collective training system of offering alternative training organised mostly in the workplace? There is an obvious dilemma here which our Norwegian case illustrates well. Using the workplace as a learning venue can under certain circumstances have positive effects on student motivation and completion compared to school-based training, although the evidence on that account is mixed. On the other hand, the study indicates that workplace-based alternative training may weaken companies' incentives to provide apprenticeships. Some employers may decide to take on students in unpaid, alternative training posts instead of offering them apprenticeships. Alternative training has the potential to alter collective training institutions by gradual 'micro' decisions, as companies may opt out of the collective system, or never enter. In the short run, it is more likely to happen in industries where the normative commitment to the collective system is low initially, for instance retail trade, which in turn may hamper efforts to expand apprenticeships into the service sector. In industries with a stronger commitment to apprenticeships, companies may use alternative training as a 'trial period' for considering whether to offer an apprenticeship. Our study suggests that negative incentive effects will differ between industries, depending on how deeply apprenticeship is rooted and how fast a student/apprentice can become productive.

The above dilemma is recognised by the national stakeholders and influences attempts to re-organise alternative training in Norway. The stakeholders have hesitated to create a fully-fledged alternative to apprenticeships because the main model with apprenticeships, although not flawless, is generally regarded as the best model. In order to not compete with the main model, alternative training has had to be somewhat of a secondbest pathway, but at the same time, decision-makers have wanted to include the most important factor of the dual collective system: the workplace-based training. A con- 
sequence of avoiding institutionalising is local, ad-hoc, solutions with poorly-planned elements of workplace training. But even with such ad-hoc solutions, our study indicates that workplace-based alternative training may have negative effects on companies incentives to provide apprenticeships.

Contrasting the Norwegian experiences with the Danish system is useful in order to analyse how different forms of organising alternative training may have different system effects. Alternative education and training in Norway and Denmark differ along two important dimensions: 1) the learning venue: whether education and training takes place mostly in a workplace or mostly in a school, and 2) the degree of institutionalisation: whether alternative education and training is a clearly organised and predictable element of the VET system or not. In the Norwegian case, the learning venue is the workplace, but the degree of institutionalisation is low. Alternative training is organised in an adhoc fashion when it becomes clear that the number of apprenticeship places is insufficient. Generally, it has not been made clear to students and others whether alternative training will be organised within a trade until a late stag $£^{5}$. In contrast, the learning venue in Denmark is mostly the school and the degree of institutionalisation is high. Training centres are responsible for organising training and the availability of such alternatives is well known.

Compared to alternative school-based training, alternative workplace training has a potential to improve students' motivation and completion, but is also the organisational form that has the largest potential to reduce the supply of apprenticeships. However, the general low degree of institutionalisation of alternative training in Norway may lessen both the potential positive and negative effects. Lack of regulation of alternative training may weaken the quality of training in the workplace and increase the danger of exploitation. On the other hand, uncertainty about whether alternative training will be offered reduces potential negative effects on companies' and students' incentives. The volume of the alternative training scheme has also so far been low, which has limited displacement effects.

A highly institutionalised system of alternative training that takes place in the workplace seems likely to have a huge disruptive potential for the apprenticeship system. If there are to be any system of alternative training and especially if it to any extent incorporates workplace training, close cooperation between the employers committed to the apprenticeship system and government seems essential. In the Norwegian case, the local training offices, which are usually owned jointly by a group of businesses and take care of many functions regarding apprenticeships, could potentially play a role in securing the quality of alternative training and limit displacement effects.

\footnotetext{
${ }^{5}$ That is beginning to change as some counties have begun to offer a guarantee to vocational students that they will either get an apprenticeship or (good quality) alternative training. The motivation has been to attract more students to vocational education.
} 


\section{References}

Aspøy, T., \& Nyen, T. (2015). Godt, men ikke for godt. Evaluering av forsterket alternativ Vg3 for elever som ikke får lareplass. Sluttrapport. Fafo-rapport 2015, 46. Oslo: Fafo.

Bergmann, S., Lechner, S., Matt, I., Riesenfelder, A., Schelepa, S., \& Wilsberger, B. (2011). Evaluierung der berbetrieblichen Lehrausbildung (BA) in Österreich. Wien: L\&R Sozialforschung.

Busemeyer, M., \& Iversen, T. (2012). Collective Skill Systems, Wage Bargaining, and Labor Market Stratification. In M. Busemeyer \& C. Trampusch (Eds.). The Political Economy of Collective Skill Formation, 205-233. Oxford: Oxford University Press.

Busemeyer, M., \& Schlicht-Schmälzle, R. (2014). Partisan power, economic coordination and variations in vocational training systems in Europe. European Journal of Industrial Relations, (20)1, 55-71. doi:10.1177/0959680113512731

Busemeyer, M., \& Trampusch, C. (2012). The Comparative Political Economy of Collective Skill Formation. In M. Busemeyer \& C. Trampusch (Eds.). The Political Economy of Collective Skill Formation, 3-40. Oxford: Oxford University Press.

Colley, H., James, D., Tedder, M, \& Diment, K. (2003). Learning as becoming in vocational education and training: class, gender and the role of vocational habitus. Journal of Vocational Education \& Training, 55 (4), 471-496. doi: $10.1080 / 13636820300200240$

Dannmarks evalueringsinstitut (2015). Evaluering av praktikcentre del 1. Analyser på tvars af centre og uddannelser. Denmark: author.

Dustman, C., \& Schoenberg, U. (2012). What makes firm-based vocational training schemes successful? The role of commitment. American Economic Journal: Applied Economics, 4 (2), 36-61. doi:10.1257/app.4.2.36

Fuller, A., \& Unwin, L. (2004). Expansive learning environments: integrating personal and organisational development. In A. Fuller, A. Munro \& H. Rainbird (Eds.). Workplace Learning in Context, 126-144. London: Routledge. doi:10.4324/9780203571644

Høst, H., Skålholt, A., \& Nyen, T. (2012). Om potensialet for å få bedriftene til å ta inn flere larlinger. NIFU Arbeidsnotat 10/2012. Oslo: NIFU.

Illeris, K. (2011). Workplace and Learning. In M. Malloch, L. Cairns, K. Evans \& B. N. O'Connor (Eds.). The SAGE Handbook of Workplace Learning, 32-45. London: SAGE Publications Ltd.

Jørgensen, C. H., \& Juul, I. (2009). Bedre samspill mellom skolepraktik og ordinær virksomhedspraktik. Undervisningsministeriets centrale analyse- og prognosevirksomhed for erhvervsuddannelserne, 2009-10.

Juul, I., \& Jørgensen, C. H. (2011). Challenges for the dual system and occupational self-governance in Denmark. Journal of Vocational Education \& Training, 63(3), 289-303. doi:10.1080/13636820.2011.560393 
Lassnig, L. (2011). The 'duality' of VET in Austria: institutional competition between school and apprenticeship. Learning as becoming in vocational education and training: class, gender and the role of vocational habitus 63 (3), 417-438. doi: $10.1080 / 13636820.2011 .590220$

Leeman, R. J., \& Imdorf, C. (2015). Cooperative VET in Training Networks: Analysing the Free-Rider Problem in a Sociology-of-Conventions Perspective. International Journal for Research in Vocational Education and Training, 2(4), 284-307. doi:10.13152/IJRVET.2.4.3

Meld. St. 20 (2012-2013). White Paper. URL: https://www.regjeringen.no/no/dokumenter/meld-st-20-20122013/id717308/

Nyen, T., Skålholt, A., Tønder, A.H. (2013). Overgangen fra fagopplæringen til arbeidslivet og videre utdanning. In H. Høst (Ed.). Kvalitet $i$ fag-og yrkesopplaringen. Fokus på skoleopplacingen, 159-200. NIFU-rapport 21/2013. Oslo: NIFU.

Nyen, T., \& Tønder, A.H. (2014). Yrkesfagene under press. Oslo: Universitetsforlaget.

Ryan, P. (2001). The School-to-Work Transition: A Cross-National Perspective. Journal of Economic Literature 39 (1), 34-92.

Solga, H., Protsch, P., Ebner, C., \& Brzinsky-Fay, C. (2014). The German vocational education and training system. Discussion Paper SP I 2014-502. Berling: WZB.

Streeck, W. (2012). Skills and Politics: General and Specific. In M. Busemeyer \& C. Trampusch (Eds.). The Political Economy of Collective Skill Formation, 317-352. Oxford: Oxford University Press.

Thelen, K. (2010). Beyond Comparative Statics: Historical Institutional Approaches to Stability and Change in the Political Economy of Labor. In G. Morgan, J.L. Campbell, C. Crouch, O.K. Pedersen \& R. Whitley (Eds.). The Oxford Handbook of Comparative Institutional Analysis. Oxford: Oxford University Press. doi:10.1093/oxfordhb/9780199233762.003.0003

Walden, G., \& Troltsch, K. (2011). Apprenticeship training in Germany still at futureoriented model for recruiting skilled workers? Journal of Vocational Education 83 Training, 63(3), 305-322. doi:10.1080/13636820.2011.570454

\section{Biographical Notes}

Tove Mogstad Aspøy is a researcher at the social science research institute Fafo in Oslo and a PhD candidate at the department of Sociology and Human Geography at the University of Oslo, Norway. Her research interests focus on vocational education and training, workplace learning, skills, competencies and job quality.

Torgeir Nyen is a researcher at the social science research institute Fafo in Oslo. His research interests include VET and education policy. With colleague Anna Hagen Tønder, he has published a book about the history and current status of Norwegian VET. 


\section{Acknowledgement}

We would like to thank our colleagues Silje Andresen, Jon Rogstad, Anna Hagen Tønder and two anonymous reviewers for valuable comments and suggestions.

The article is based on the authors' evaluation of a recent attempt to improve an alternative school based route to vocational qualifications in Norway. The evaluation was commissioned by the The Norwegian Directorate for Education and Training. 